\title{
The effects of root temperature on water flux, potential and root resistance in sunflower
}

\author{
T Ameglio 1, J Morizet 2, P Cruiziat 1, M Martignac 2 \\ with the technical collaboration of $\mathrm{C} \mathrm{Bodet}{ }^{1}$ and $\mathrm{H}$ Raynaud ${ }^{2}$ \\ 1 INRA, Centre de Recherches Clermont-Ferrand, Theix, Laboratoire de Bioclimatologie, \\ Domaine de Crovelle, 63039 Clermont-Ferrand Cedex; \\ 2 INRA, Centre de Recherches Clermont-Ferrand, Theix, Station d'Agronomie, \\ 12, avenue du Brezet, 63039 Clermont-Ferrand Cedex, France
}

(Received 26 September 1989; accepted 6 February 1990)

\begin{abstract}
Summary - We observed the effects of a sharp fall in temperature of the root medium over a 24-h period, on flux and water status in sunflowers, under controlled conditions using a device which simultaneously recorded the absorption, the transpiration, the water potential of the leaves and the temperature of the nutrient solution. For the lowest temperatures, we observed that the water fluxes were temporarily uncoupled and that a water deficit appeared in the plant inducing a fall in leaf water potential. Then transpiration itself decreased, following a very similar pattern to that of absorption. We were able to observe the fall in root conductivity below temperatures of $10.0^{\circ} \mathrm{C}$. For the lowest temperatures, water resistance increased dramatically and rapidly, and decreased a few $\mathrm{h}$ later. On the contrary, above the threshold temperature of $6^{\circ} \mathrm{C}$ (where both phenomena occurred successively) the water root resistance increased after a few $\mathrm{h}$. Finally, raising the temperature to $20.0^{\circ} \mathrm{C}$ caused the rise in leaf water potential to nearly the control value. However, although the water fluxes increased, they remained lower than their initial values.
\end{abstract}

root temperature / water flux / potential / root resistance / acclimatization

Résumé - Effets de la température racinaire sur le flux hydrique, le potentiel hydrique et la résistance racinaire chez le tournesol. Nous avons suivi l'influence d'un abaissement de la température de la solution nutritive $\left(20^{\circ} \mathrm{C}\right.$ a $\left.2,5^{\circ} \mathrm{C}\right)$, pendant $24 \mathrm{~h}$, sur les flux et l'état hydrique d'un tournesol en conditions contrôlées, grâce à un dispositif mesurant simultanément et en continu (fig 1): l'absorption, la transpiration, le potentiel hydrique foliaire et la température du milieu racinaire. Pour les températures les plus froides nous observons un découplage du flux d'absorption par rapport à la transpiration, conduisant au déficit hydrique du végétal (fig 2). Le potentiel hydrique foliaire chute. Ce découplage n'est que temporaire, la transpiration venant rapidement s'aligner sur l'absorption. Nous pouvons alors quantifier la baisse de la conductivité hydraulique des racines à partir d'une température de $10^{\circ} \mathrm{C}$ (fig 5). Pour les températures les plus froides $\left(2,7^{\circ} \mathrm{C}\right.$ et $4,2^{\circ} \mathrm{C}$ ), la résistance hydraulique (fig 4) augmente fortement et très rapidement pour diminuer sensiblement quelques $h$ après le choc ("acclimatation»). Par contre, au-dessus d'une température "charnière" de $6{ }^{\circ} \mathrm{C}$ (où l'on retrouve les 2 tendances), la résistance hydraulique racinaire n'augmente qu'après plusieurs $h$. Enfin le potentiel hydrique foliaire retrouve un niveau proche de celui qui précédait le choc, alors que les flux hydriques tout en augmentant, restent inférieurs à leurs valeurs initiales.

température racinaire / flux hydrique / potentiel / résistance racinaire / acclimatation

\footnotetext{
* Correspondence and reprints
} 


\section{INTRODUCTION}

Many works have shown the influence of root temperature on plant water status. As far back as the last century, Sachs (1875) (cited in Kramer (1940)) noticed that tobacco plants wilted at a root temperature of $3.5^{\circ} \mathrm{C}$ and recovered their turgor when the temperature was raised to $18^{\circ} \mathrm{C}$.

Thus, the phenomenon has been known for a long time and in the reviews by Cooper (1973) and Cornillon (1980) we find the description of relations between root temperature and water absorption. These authors have also presented a few hypotheses on the mechanisms which are likely to account for the phenomena involved, especially those concerning the root conductivity of water.

If we refer to the electrical analogy (Van den Honert, 1948), water movements in the soilplant-atmosphere continuum are controlled by water potential differences and resistances met along the course. Plant resistance to water uptake is usually subdivided into partial resistances connected in series. Thus, in the liquid phase, resistances occur successively in roots, stems, petioles and leaves. Among these, the principal resistance is often attributed to roots (Kramer, 1946; Stoker and Weatherley, 1971; Black, 1979a). In the same manner, in studies of relations between root medium temperature and water absorption, as far back as 1897 in the works of Kosarov (cited in Kramer (1940)), then later in the studies made by Ardnt (1937), the idea of an important and variable root resistance to water uptake at root level was foreseen through experiments on living and dead root systems, or after root removal (Kramer, 1933; Mingeau, 1969).

Generally, in previous works the changes in plant water status according to the substrate temperature were characterized by 1 or 2 measures: water absorption flux (Vesque, 1878; Clements and Martin, 1934; Schroeder, 1939; Shirazi et al, 1975), transpiration flux (Delucia, 1986), both fluxes (Nordin, 1976), or the monitoring of the water potential, particularly in the leaves (Black, 1979b). However, as far as we know, these 3 quantities have never been observed at the same time. Yet their knowledge is necessary to check that the rate of flux is conservative (ie, absorption equals transpiration, which is the necessary condition for utilising the electrical analogy, and calculating the root resistance to water uptake).
We present here an experiment on sunflower seedlings; the objective was to determine the effects of a sharp fall in temperature of the root medium on water absorption and on root conductivity of water. The experiment was conducted under controlled conditions using a device which simultaneously recorded the absorption, transpiration, water potential of the leaves and temperature of the nutritive solution. We also carefully observed the reactions of the root system after the chilling shock for a 24-h period to provide evidence for possible acclimatization processes, an aspect that has been little considered up to now.

\section{MATERIALS AND METHODS}

\section{Plant material}

The experiment was carried out on 1-month old sunflower seedlings (Helianthus annuus L, Primasol variety), cultivated on a nutrient solution in a culture chamber under the following conditions:

- temperature $=20^{\circ} \mathrm{C} \pm 0.5^{\circ} \mathrm{C}$;

- photoperiod $=12 \mathrm{~h}$;

- photon flux density (top of the plant) $=400$

$\mu \mathrm{mol} \cdot \mathrm{m}^{-2} \cdot \mathrm{s}^{-1}$;

- day relative humidity $=60 \% \pm 5 \%$;

- night relative humidity $=75 \% \pm 5 \%$.

Absorption, transpiration and nutrient solution temperatures were continuously monitored using a transpiration chamber and a device for measuring the absorption (fig 1), both placed in an air-conditioned chamber with the same temperature, relative humidity and lighting as in the culture chamber. The leaf water potential was measured periodically with a dew point hygrometer.

\section{Measuring devices}

\section{Transpiration chamber (fig 1)}

The aerial part of the plant was put in a transpiration chamber, as already described (Morizet et al, 1987). During the tests, the relative humidity was stabilized at $60 \pm 0.5 \%$. Lighting was provided by mercury vapour lamps (Osram HQITS) with a photon flux density on leaves of $400 \mu \mathrm{mol} \cdot \mathrm{m}^{-2} \cdot \mathrm{s}^{-1}$.

Transpiration was calculated from the air delivery (mass flow meter, FC 262 Tylan) and from the inlet and outlet dew point temperatures (dew point hygrometers type DEW-10; General Eastern). 


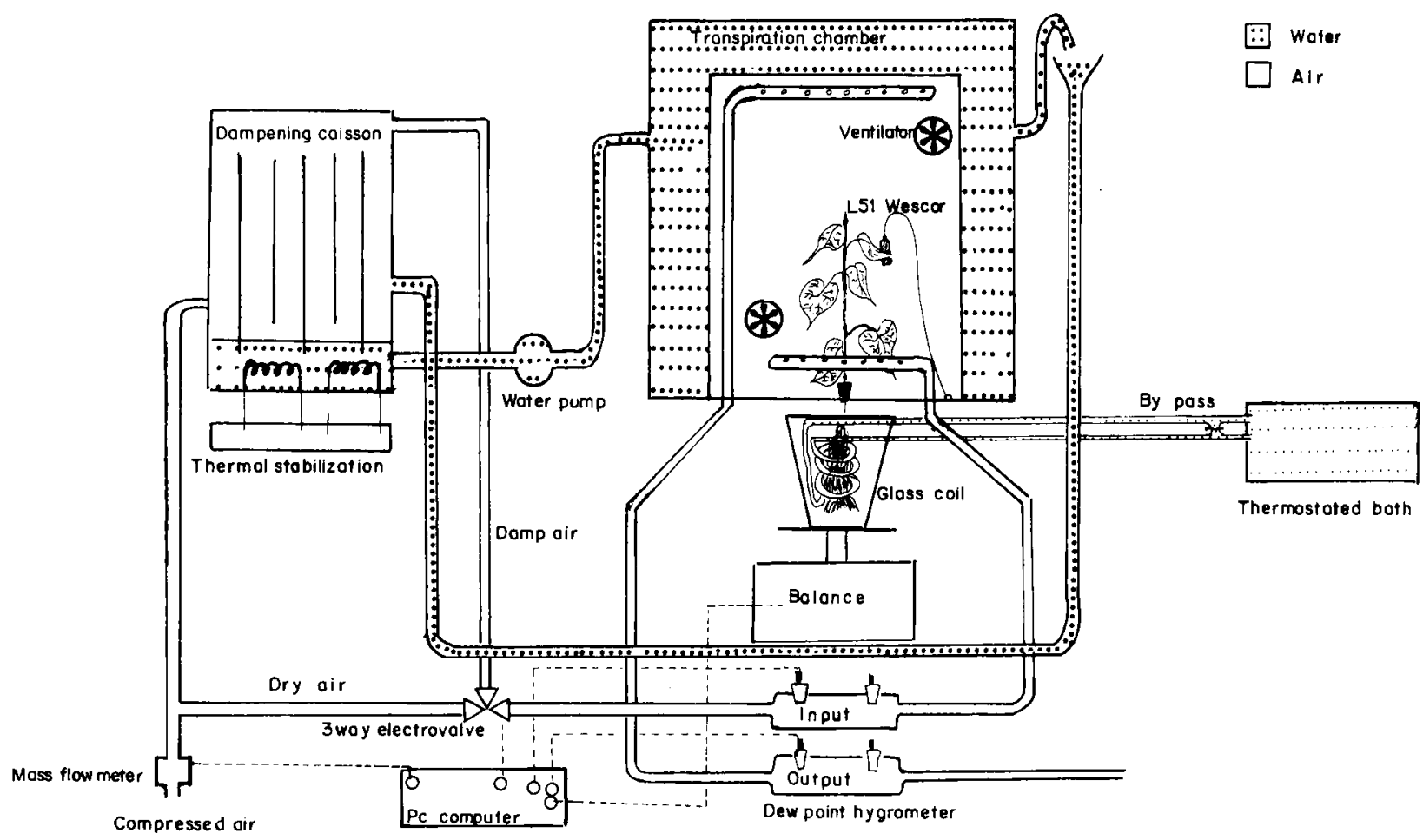

Fig 1. Diagram of the equipment used for continuous recording of transpiration (transpiration chamber), absorption (balance). The chilling shock apparatus is also represented by the glass coil and thermostated bath.

\section{Device for measuring absorption}

Absorption was measured by weighing the root medium with a recording balance (Mettler 3600 , with a 3.6 $\mathrm{kg}$ capacity and a centigram sensitivity). The nutrient solution was in an insulated vase into which the roots were plunged. The oxygenation of the nutrient solution was provided by a "bubble system" which was stopped during weighing.

\section{Leaf water potential and measure of temperature}

The leaf water potential was measured in situ by means of dew point microhygrometers (L51 Wescor); 2 sensors were put on the third and fourth leaves from the base of the stalk. Thermometers with analogous output indicated the nutrient solution temperature.

\section{Inducing the chilling shock}

The chilling shock was obtained by decreasing the nutrient solution temperature by means of a glass coil surrounding the roots, in which glycol water from a thermostated bath circulated (fig 1). The initial temperature was maintained at $20^{\circ} \mathrm{C}$. The shock consisted of chilling the glycol solution to the desired temperature in the thermostated bath, then opening the "bypass" which allowed water to circulate in the coil (fig 1). A wide range of temperatures was tested from $2.5^{\circ} \mathrm{C}-$ $20^{\circ} \mathrm{C}$. The time lag to obtain chilling of the root medi- um varied depending on the desired temperature: for example, the temperature of $2.5^{\circ} \mathrm{C}$ was obtained in about $90 \mathrm{~min}$.

\section{Control and acquisition of data}

Data was recorded by computer every $2.5 \mathrm{~min}$. Averages for 10 min over several days are used in the graphic representation of the data.

\section{Calculation of root resistance to water uptake}

By applying the electrical formula, the apparent root resistance to water uptake, $R_{p}$, can be calculated as:

$$
T_{r}=\frac{\psi_{s}-\psi_{f}}{R_{p}}
$$

where

$T_{r}=$ transpiration: $\mathrm{cm}^{3} \cdot \mathrm{s}^{-1} \cdot \mathrm{cm}^{-2}=\mathrm{cm}^{-\mathrm{s}^{-1}}$;

$\psi_{s}=$ water potential of the solution = osmotic potential of the nutrient solution $=-0.034 \mathrm{MPa}$ at $20^{\circ} \mathrm{C}$;

$\psi_{\mathrm{f}}=$ leaf water potential : $\mathrm{MPa}$;

$R_{p}=$ plant resistance : $M P a \cdot s^{\circ} \mathrm{cm}^{-1}$.

Because the root hydraulic resistance is generally considered as the main resistance, and since the root system alone is submitted to low temperatures, we 
equated (in a first approximation) the root resistance, $R_{r}$, to the "plant" resistance, $R_{p}$.

The application of the electrical analogy for calculating the root resistance supposes the flux to be conservative, ie absorption equals transpiration. Actually, a growth uptake occurs when there is no water stress, but it only represents a negligible quantity compared with inlet and outlet fluxes.

In order to obtain the best possible conservative flux conditions, we selected the data corresponding to the following rules:

1) a minimum period of $2 \mathrm{~h}$ after the shock (stabilization of temperature);

2) a maximum $\psi_{\mathrm{f}}$ variation of $0.05 \mathrm{MPa}$ during a period of $20 \mathrm{~min}$;

3) a 10\% maximum variation in transpiration during a period of $20 \mathrm{~min}$;

4) a $10 \%$ maximum variation in absorption during a period of $20 \mathrm{~min}$;

5) a $10 \%$ maximum deviation in difference between the 2 fluxes during a period of $20 \mathrm{~min}$;

6) a calculation of root resistance values has been made only for the light period measurements, when fluxes are large enough and because at night, the variation between the two fluxes is over $10 \%$.

To compare the results, the flux value refers to the leaf surface area, which we determined before and after each experiment. The leaf water potential value was calculated as the mean value of the 2 water potential measures of $\Psi_{\mathrm{f}}$. Before determining the effect of temperature on root resistance, we first made sure that the values of the root resistance obtained at $20^{\circ} \mathrm{C}$, before the chilling shock, were not statistically different between the plants; they were on average $0.52 \pm 0.0410^{5} \cdot \mathrm{MPa}^{\mathrm{s}} \mathrm{cm}^{-1}$.

\section{RESULTS}

\section{Absorption and transpiration flux-water balance}

In order to be clear, only two experiments will be presented here. In the first, the root medium temperature was always maintained at $20^{\circ} \mathrm{C}$; this was our reference. In the second, the temperature was maintained at $5.8^{\circ} \mathrm{C}$.

\section{Root temperature at $20^{\circ} \mathrm{C}$ (fig 2)}

In daytime, the transpiration flux and absorption flux levels were almost identical. However, the absorption flux was somewhat higher - about $2 \%$ - and this positive balance can be attributed to the volume growth of the plant parts. As soon as the chamber was in the dark, the transpiration flux along with the absorption flux decreased quickly, then both of them came to a plateau. During the night, the absorption flux rose by $\approx$ $20 \%$ compared to the transpiration flux. The next day, on illumination the climatic demand created a rather rapid increase in transpiration, then with a very short delay in the absorption flux. The flux progressive increase over the 3 days showed a growth of the plant evidenced by a $32 \%$ leaf expansion.

The leaf water potential decreased by $\approx 0.05$ $\mathrm{MPa}$ during the day. During the night, the plant rehydrates and the next day the water potential was $-0.2 \mathrm{MPa}$ just before lighting instead of the $-0.32 \mathrm{MPa}$ noted the evening before. Due to the relatively high value of air humidity $(60 \%)$ transpiration during the night is fairly significant and therefore no equilibrium between the osmotic potential of the solution and the leaf water potential can be achieved. On illumination, it dropped sharply to $-0.32 \mathrm{MPa}$, then recovered to -0.27 $\mathrm{MPa}$. This phenomenon can be explained by the fact that at that moment the stomata quickly opened inducing a transpiration flux which was not locally and immediately compensated by an inlet flux.

\section{Chilling shock at $5.8^{\circ} \mathrm{C}$ (fig 3)}

The same phenomena as those described in the previous experiment were observed during the preliminary phase at $20^{\circ} \mathrm{C}$.

When the root medium was chilled to $5.8^{\circ} \mathrm{C}$, the absorption flux dropped rapidly, whereas transpiration remained at the same level for about $2 \mathrm{~h}$ after the chilling shock. The inlet and outlet water fluxes were temporarily uncoupled. A water deficit appeared in the plant, inducing a fall in leaf water potential.

Then the transpiration itself decreased, following a very similar pattern to that of absorption. The water potential reached its lowest level, -0.8 $\mathrm{MPa}$, and the plant wilted.

Finally, $\approx 150 \mathrm{~min}$ after the shock, absorption and transpiration processes started to recover without any modification in the experimental conditions, and simultaneously the water potential rose to $-0.55 \mathrm{MPa}$.

On the second day, at the end of the night, the plant had recovered its initial turgidity although the roots had been maintained at $5.8^{\circ} \mathrm{C}$. When lit, transpiration increased at a rhythm almost identical to that of control plants but water absorption could not follow. The result was an in- 


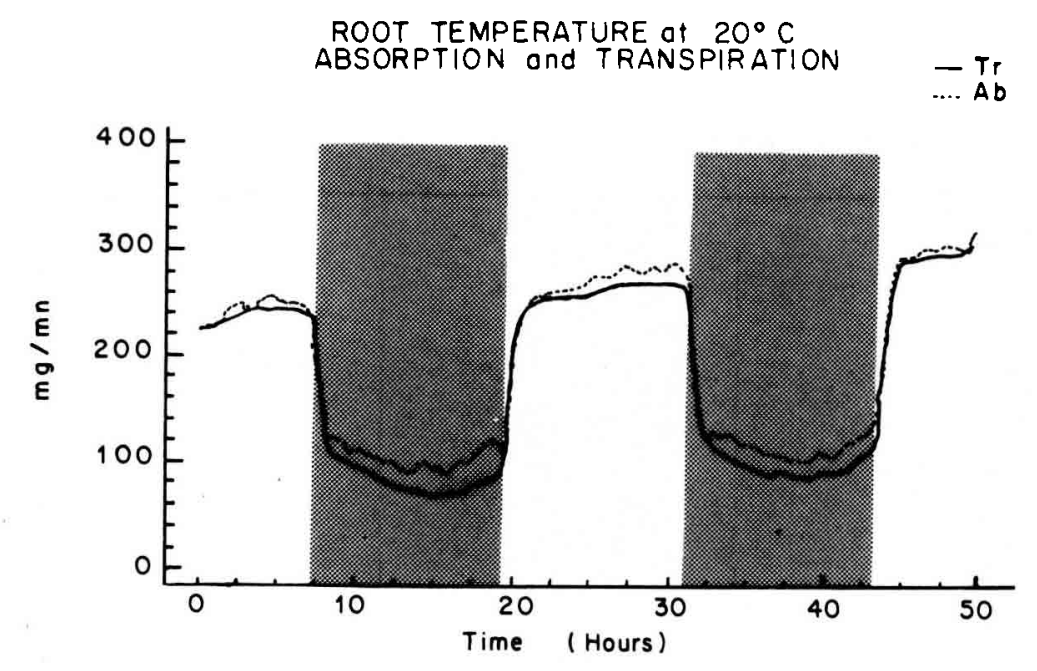

LEAF WATER POTENTIAL (MPa)

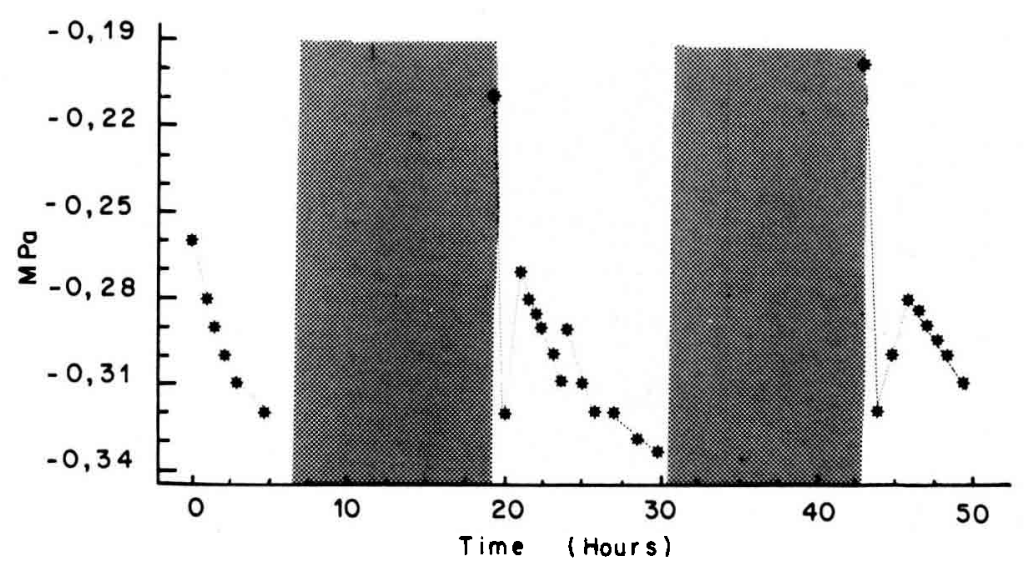

Fig 2. Time course over a 3-day period of transpiration $(-)$ absorption (.....) and leaf water potential (*.....*) under standard conditions (the root medium temperature being kept to $20^{\circ} \mathrm{C}$ ). The shaded area corresponds to the night period.

creased water deficit; the plant wilted again, and the potential dropped from -0.5 to $-0.8 \mathrm{MPa}$.

Raising the temperature to $20^{\circ} \mathrm{C}$ resulted in the recovery of turgidity and the water potentials quickly reached their former level; however, although the water fluxes increased, they remained lower than the initial values.

\section{Root resistance to water uptake (Rr)}

\section{$\mathbf{R}_{\mathrm{r}}$ evolution after the chilling shock (fig 4)}

The effect of temperature varied markedly with the chilling shock intensity. First of all, when the temperature of the nutrient solution was $\geq$ $10.2^{\circ} \mathrm{C}$, root resistance was the same as in the $20^{\circ} \mathrm{C}$ test.

On the contrary, with the lowest temperatures $\left(2.7^{\circ} \mathrm{C}\right.$ and $\left.4.2^{\circ}\right)$ water resistance increased dramatically and very rapidly. After a few hours, it began to drop and kept doing so until the following morning.

The chilling shock at $8.2{ }^{\circ} \mathrm{C}$ did not modify root behaviour on the first day. Root resistance increased only during the following day as though the temperature effect had been delayed.

The temperature of $5.8^{\circ} \mathrm{C}$ was a threshold temperature because both phenomena occurred successively: a rapid rise in $R_{r}$ was followed by a decline during the afternoon, then $R_{r}$ again increased the following morning.

\section{Variation in $\mathbf{R}_{\mathbf{r}}$ according to root temperature (fig 5)}

Taking into account the overall results concerning the evolution of root resistance according to nutrient solution temperature and disregarding 


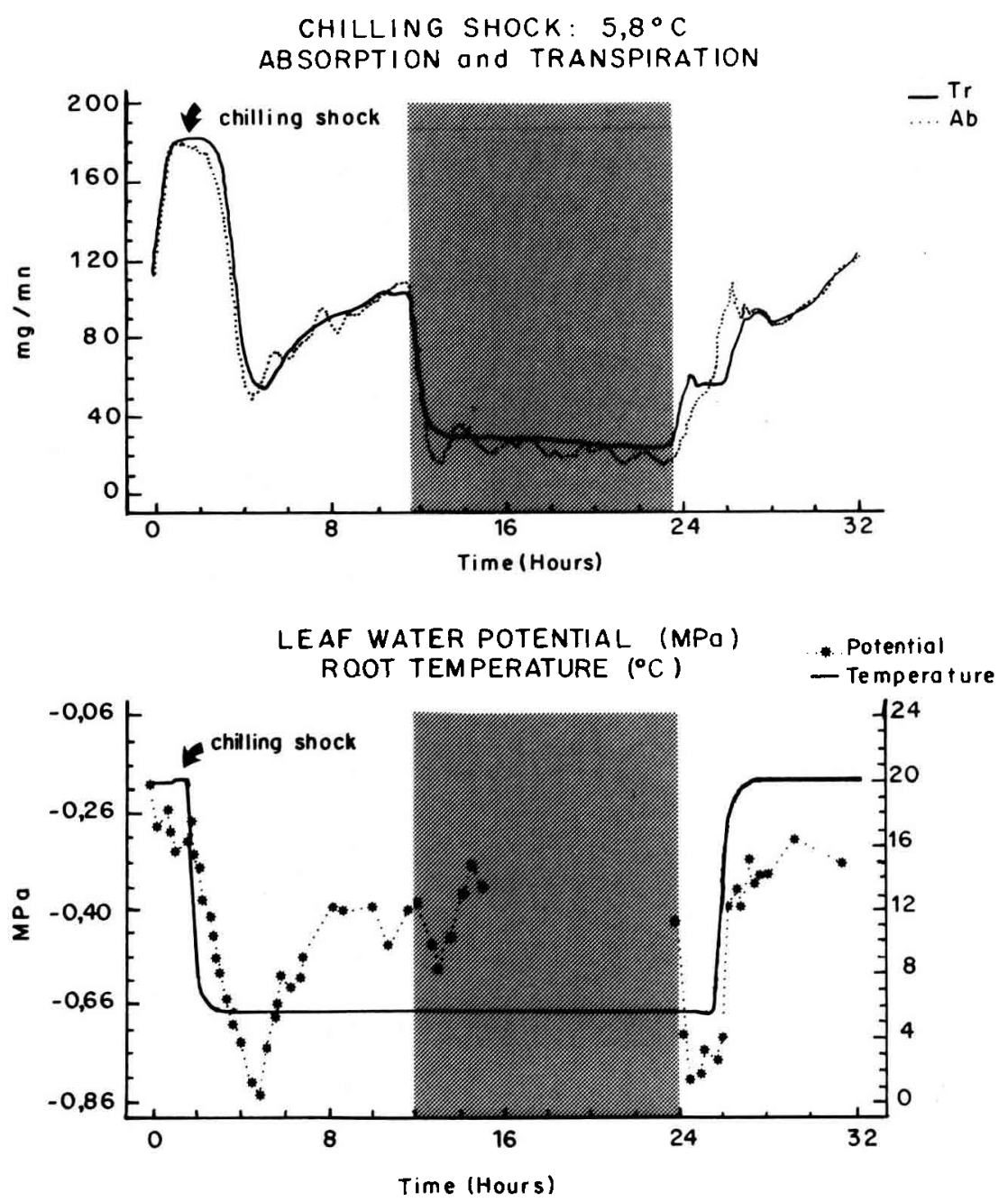

Fig 3. Time course of transpiration, absorption, leaf water potential and temperature of the root solution under chilling shock conditions. Fig 3a : transpiration (- $(\longrightarrow)$ and absorption (......). Fig 3b: leaf water potential (*.....*) and temperature ( $\longrightarrow$ ) of the root solution. The shaded area corresponds to the night period.

the above-described evolution, we can describe the variation of $R_{r}$ with temperature by the following statistical expression:

$$
\begin{aligned}
R_{r} & =4.64 \cdot 10^{6} \cdot \theta^{-1.55} \\
\left(r=-0.92 \text { and } r^{2}\right. & =0.85 \text { significance level }=0.05)
\end{aligned}
$$

where $R_{r}=$ root resistance: $M p a \cdot s \cdot \mathrm{cm}^{-1} ; \theta=$ nutrient solution temperature: ${ }^{\circ} \mathrm{C}$.

The scattering of the points for the same temperature reflected the evolution observed previously.

When the temperature was above $6{ }^{\circ} \mathrm{C}$ there was little variation in root resistance compared with the $R_{r}$ values at $20^{\circ} \mathrm{C}$. On the other hand, when the temperature was under $6{ }^{\circ} \mathrm{C}, \mathrm{R}_{\mathrm{r}}$ changed dramatically rising to 14 or $15 \cdot 10^{5} \cdot \mathrm{MPa} \cdot \mathrm{s} \cdot \mathrm{Cm}^{-1}$ at $2.7^{\circ} \mathrm{C}$.

\section{DISCUSSION AND CONCLUSIONS}

The results obtained confirmed the existence of a root temperature threshold, under which water extraction is reduced; this threshold varies greatly with plant species (Kramer, 1942; Bohning and Lusanandana, 1952; Cornillon, 1974).

With the sunflower variety tested, a temperature under $8^{\circ} \mathrm{C}$ was necessary to obtain a slight decrease in water extraction. But the temperature threshold under which effects on flux were significant was $\approx 6{ }^{\circ} \mathrm{C}$. According to Nordin (1976), the root temperature drop implies a decrease in water absorption and transpiration, transpiration always being lower than absorption. It appears to correspond to an increase in the stomatal resistance without a decrease in water conductivity through the roots. Aston and Lawlor 


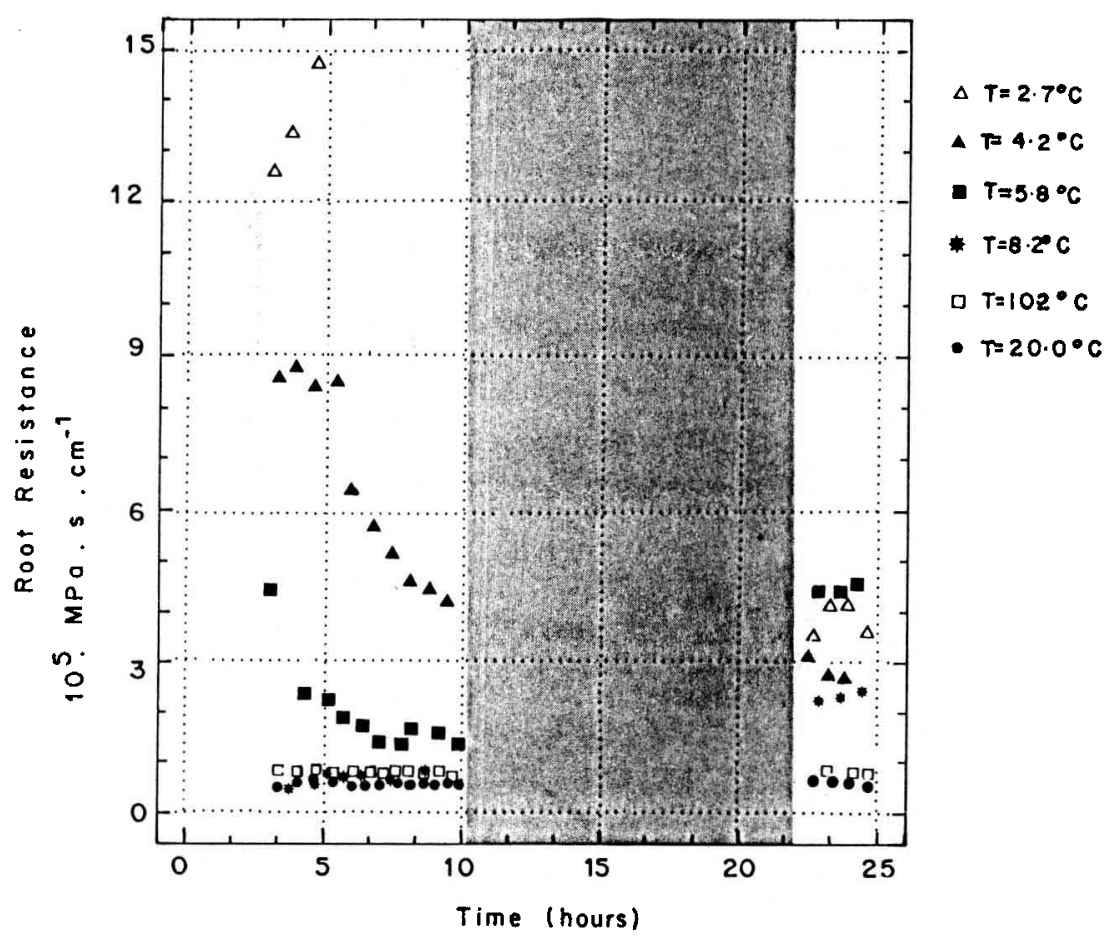

Fig 4. Time course of the response of chilling shock of root resistance to water uptake. Temperatures of chilling ranges from 2.7 to $10.2^{\circ} \mathrm{C} ; 20^{\circ} \mathrm{C}$ is the reference temperature. The shaded area corresponds to the night period.

(1979) also observed a decrease in the absorption and an increase in the stomatal resistance, with no change in leaf water potential. We observed that the cold temperature first affected root water resistance then stomatal resistance. The successive phenomena explained the decrease in the water potential of the leaves, which

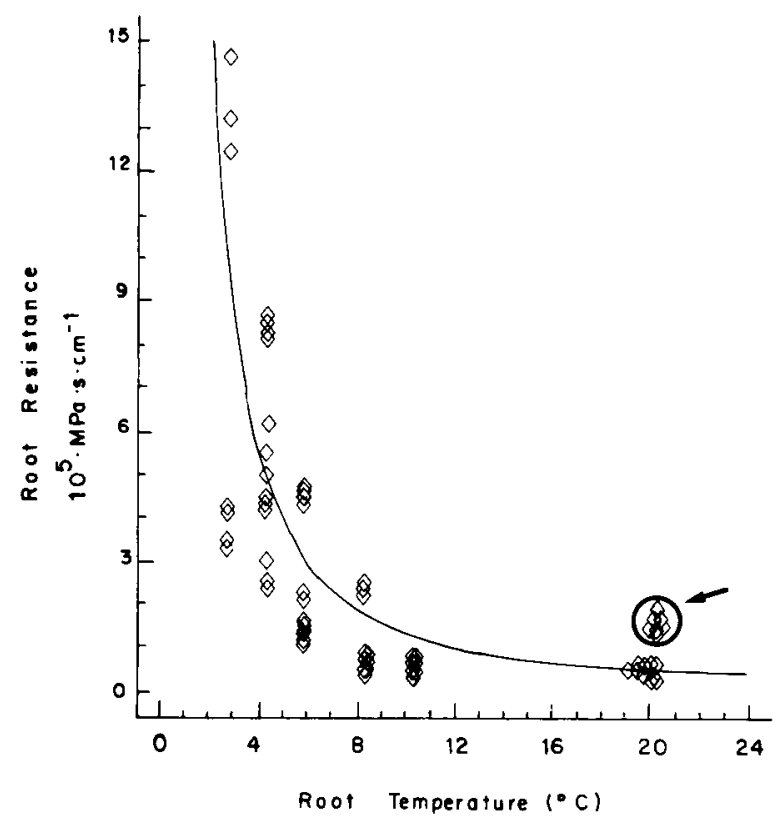

Fig 5. Variation of the root resistance to water with temperature. The encircled points at $20^{\circ} \mathrm{C}$ represent values obtained after a chilling shock. decreased to $-1.2 \mathrm{MPa}$ at $2.7^{\circ} \mathrm{C}$. Absorption seemed to "control" transpiration under chilling shock conditions.

\section{Processes involved in $R_{r}$ variation with temperature}

Kramer (1940) presented the first hypothesis, which is still valid, on the processes that explain the influence of low temperatures on water absorption. The most widespread hypothesis in the literature (Kuiper, 1964; Dalton and Gardner, 1978 ) is that of the role of water viscosity. On the contrary, Black (1979b) considered that water viscosity was not important. Indeed, stem or petiole chilling had no effect, whereas root chilling led to a strong reversible wilting (80\% reduction of the absorption), whence the idea of a major biological aspect in the absorption reduction.

Kuiper (1964) suggested a critical temperature threshold above which only the water viscosity would have an effect. Below this threshold, on the contrary, root resistance would become a major parameter due to a change in membrane structure.

Kaufmann (1975, 1977) and Grossnickle (1988) drew charts showing the evolution of water viscosity compared with that of water resis- 
tance as a function of root temperature; the negligible role of viscosity in roots was obvious at very low temperatures.

Resistance as calculated by the HagenPoiseuille equation is inversely proportional to viscosity. Taking values at $0{ }^{\circ} \mathrm{C}$ and $20^{\circ} \mathrm{C}$ gives a change in resistance between these temperatures of only $7 \%$ which is to be compared with an observed change of between $1800 \%$ and $2800 \%$. Although theoretical, the calculation gave us an indication of the actual impact of water viscosity when water resistance varies after a chilling shock.

The decrease in absorption, and then the increase in water resistance through the roots could partially result from the structural changes in the membranes (Kuiper, 1964, 1972; Lyons et al, 1979). At the critical temperature, the membrane structure would change from "a liquidcrystal" state to a "solid-gel" state with an accompanying decrease in cell permeability, an increase in water flux resistance and a decrease in membrane-related metabolic activity. This decrease is often characterized by a sharp drop in the curve, showing activation power at the temperature threshold in the Arrhenius plots (Kuiper and Kuiper, 1978; Wilson, 1983; De Lucia, 1986).

The low temperature also had an effect on protein structure (Mazliak, 1981; Caldwell, 1987; Caldwell et Whitman, 1987) and on intermediary metabolism; indeed Cornillon (1977a, b) noted an accumulation of free amino-acids which tends to cause a rise in protoplasm viscosity. It seems then that it is the association of both membrane and protoplasm modifications at the molecular level (lipids and proteins in particular) which results in an overall increase in water resistance through the roots.

\section{Time course of root water resistance after a chllling shock}

Although major molecular changes can explain the initial increase in water resistance at low temperatures, they are probably also involved in its further time course.

As a matter of fact, we observed a flux increase and a decrease in root water resistance in sunflower at the lowest temperatures; this phenomenon can be considered as a form of plant acclimatization at low temperatures.
As far as we know, few studies have dealt with this dynamic aspect of the response of root resistance at low temperatures, especially over a short period. Similar studies, also on sunflower, (Bohning and Lusanandana, 1952), showed that turgor recovery took place about $1.30 \mathrm{~h}$ after the strong wilting that was associated with a severe and rapid drop in root temperature.

Many studies on chilling tolerance can provide information on structural changes. Markhart et al (1979), comparing a chilling-sensitive plant (glycine) with a chilling-tolerant plant (Brassica oleracea var botrytis), concluded that the fatty acid composition in the root system could be responsible for their differing behaviour.

It seems that the fatty acid degree of unsaturation was not closely related to the difference between species, but that unsaturated fatty acids of chilling-tolerant plants increased more than unsaturated fatty acids of chilling-sensitive plants during acclimatization to chilling temperatures.

In the same manner, Cornillon $(1977 a, b)$ Lyons et al (1979) and Levitt (1980) have shown among several annual plant species (eg cotton, sunflower) that the ratio of unsaturated fatty acids to saturated fatty acids was higher for chilling-tolerant plants than for chilling-sensitive plants at low temperatures. Membrane fluidity appears to be preserved due to unsaturation of the fatty acid chains.

Emphasis now tends to be placed on the importance of hormones (Mizrahi and Richmond, 1972; Collins and Morgan, 1980; Markhart, 1982, 1983; Smith and Dale, 1988) and proteins in membrane permeability change to water uptake (Mazliak, 1981; Caldwell, 1987; Caldwell et Whitman, 1987).

The "acclimatization" at low temperatures can be explained either by a change in membrane structure or by a change in lipid composition (Grenier et al, 1973; Markhart et al, 1980). Indeed, they observed a change in degree of fatty acid unsaturation $4 \mathrm{~h}$ after the chilling shock. This possibly resulted from hormonal change (abscisic acid synthesis activation?). With regard to lipid modification, it always depends on enzymatic change (Mazliak, 1981).

To sum up, the decrease in root temperature led to a sharp drop in water absorption, which was temporarily dissociated from transpiration. A water deficit occurred in the plant, which then wilted. The resistance to water flux was strongly increased at the critical temperature of $6^{\circ} \mathrm{C}$, 
which may correspond to the "hardening of the membrane structure" occurring with a change from liquid-crystal to solid-gel state.

The reduction of this effect with time for the lowest temperatures indicated an acclimatization to low temperatures. The latter can perhaps be explained by a change in membrane structure, possibly through changes in fatty acid composition, whether or not hormones are responsible (eg absicic acid). On the other hand, we have no explanatory hypothesis for the delayed increase in root resistance to water uptake for intermediate temperatures $\left(7-8^{\circ} \mathrm{C}\right)$. The fact that 3 situations occurred at the critical temperature of $6{ }^{\circ} \mathrm{C}$ shows that water transfer resistance is a very complex phenomenon.

\section{REFERENCES}

Arndt $\mathrm{CH}$ (1937) Water absorption in the cotton plant as affected by soil and water temperatures. Plant Physiol 12, 703-720

Aston MJ, Lawlor DW (1979) The relationship between transpiration, root water uptake, and leaf water potential. J Exp Bot 30, 169-181

Black CR (1979a) The relationship between transpiration rate, water potential, and resistances to water movement in sunflower (Helianthus annuus L). J Exp Bot 30, 235-243

Black CR (1979b) The relative magnitude of the partial resistances to transpirational water movement in sunflower (Helianthus annuus L). J Exp Bot 30 , 245-253

Bohning RH, Lusanandana B (1952) A comparative study of gradual and abrupt changes in root temperature on water absorption. Plant Physiol 27, 475488

Caldwell CR (1987) Temperature-induced protein conformational changes in barley root plasma membrane-enriched microsomes. II. Intrinsic protein fluorescence. Plant Physiol 84, 924-929

Caldwell CR, Whitman CE (1987) Temperatureinduced protein conformational changes in barley root plasma membrane-enriched microsomes. I. Effect of temperature on membrane protein lipid mobility. Plant Physiol 84, 918-923

Clements FE, Martin EV (1934) Effect of soil temperature on transpiration in Helianthus annuus. Plant Physiol 9, 619-630

Collins JC, Morgan M (1980) The influence of temperature on the abscisic acid stimulated water flow from excised maize roots. New Phytol 84, 19-26

Cooper AJ (1973) Root temperature and plant growth. Res Rev CAB East Malling, No 4, Commonwealth Agricultural Bureaux, Slough, GBR, 72 pp
Cornillon P (1974) Comportement de la tomate en fonction de la température du substrat. Ann Agron $25,753-777$

Cornillon P (1977a) Influence de la température du substrat sur la composition des racines et des limbes de tomates. Implications concernant l'absorption hydrique. Ann Agron 28, 277-289

Cornillon P (1977b) Effet de la température des racines sur l'absorption des éléments minéraux par la tomate. Ann Agron 28, 409-423

Cornillon P (1980) Etude bibliographique. Incidence de la température des racines sur la croissance et le développement des plantes. Ann Agron 31, 6384

Dalton FN, Gardner WR (1978) Temperature dependence of water uptake by plant roots. Agron J 70 , 404-406

Delucia EH (1986) Effect of low root temperature on net photosynthesis, stomatal conductance and carbohydrate concentration in Engelmann spruce ( $P$ icea engelmannii Parry ex Engelm) seedlings. Tree Physiol 2, 143-154

Grenier G, Mazliak P, Tremolieres A, Willemot C (1973) Influence du froid sur la synthèse des acides gras dans les racines de deux variétés de luzerne, l'une très résistante et l'autre moins résistante au froid. Physiol Vég 11, 253-265

Grossnickle SC (1988) Planting stress in newly planted jack pine and white spruce. 1. Factors influencing water uptake. Tree Physiol 4, 71-83

Kaufmann MR (1975) Leaf water stress in Engelmann spruce. Influence of the root and shoot environments. Plant Physio/ 56, 841-844

Kaufmann MR (1977) Soil temperature and drying cycle effects on water relations of Pinus radiata. Can $J$ Bot 55, 2 413-2 418

Kramer PJ (1933) The uptake of water through dead root systems and its relation to the problem of absorption by transpiring plants. Am $J$ Bot 20, 481482

Kramer PJ (1940) Causes of decreased absorption of water by plants in a poorly aerated media. $A m J$ Bot 27, 216-220

Kramer PJ (1942) Species differences with respect to water absorption at low soil temperature. $A m J$ Bot $29,828-832$

Kramer PJ (1946) Root resistance as a cause of decreased water absorption by plants at low temperatures. Plant Physiol 15, 63-79

Kuiper F, Kuiper PJC (1978) Application of the entropy-enthalpy relationship in water transport through plant roots. Physiol Plant 43, 121-125

Kuiper PJC (1964) Water uptake of higher plants as aftected by root temperature. Meded Landbouwhogesch Wageningen 64, 1-11

Kuiper PJC (1972) Water transport across membranes. Annu Rev Plant Physiol 23, 157-172 
Lewitt J (1980) Responses of plants to environmental stresses, vol 1, Chilling, freezing and high temperature stresses. Academic Press, 2nd ed, 3-67

Lyons JM, Raison JK. Steponkus PL (1979) The plant membrane in response to low temperature: an overview. In: Low temperature stress in crop plants. The role of membrane (Lyons JM, Graham D, Raison JK, eds), Academic Press, New York, 1-24

Markhart AH III, Fiscus EL, Naylor AW, Kramer PJ (1979) Effects of temperature on water and ion transport in soybean and broccoli systems. Plant Physiol 64, 83-87

Markhart AH III, Peet MM, Sionit N, Kramer PJ (1980) Low temperature acclimation of root fatty acid composition, leaf water potential, gas exchange and growth of soybean seedlings. Plant Cell Environ 3, 435-441

Markhart AH III (1982) The interaction of temperature and abscisic acid on water transport through root systems. In: Abstract collection, vol 1, 21. Int Hortic Congr Hamburg, (DEU), 1982/08/29-/09-04. International Society for Horticultural Science, The Hague, p 1503

Markhart AH III (1984) Amelioration of chilling-induced water stress by abscisic acid-induced changes in root hydraulic conductance. Plant Physiol 74, 81-83

Mazliak P (1981) Régulation à court terme et à long terme de l'activité des enzymes membranaires par la température. Physiol Vég 19, 543-563

Mingeau M (1969) Action de la nutrition minérale sur l'économie de l'eau dans la plante.l. Equilibre absorption-transpiration. Ann Agron 20, 263-276

Mizrahi Y, Richmond AE (1972) Hormonal modification of plant response to water stress. Aust $J$ Biol Sci $25,437-442$
Morizet J, Falcimagne R, Martignac M (1987) Dispositif expérimental permettant de mesurer simultanément l'absorption hydrique et la transpiration d'une jeune plante cultivée sur sol. Premiers résultats obtenus. Agronomie 7, 541-546

Nordin A (1976) Effects of water stress and abscisic acid on transpiration regulation in wheat. Physiol Plant 38, 233-239

Schroeder RA (1939) The effect of root temperature upon the absorption of water by the cucumber. $M O$ Agric Exp St Bull (309), 27 pp

Shirazi GA, Stone JF, Croy LI, Todd GW (1975) Changes in root resistance as a function of applied suction, time of day, and root temperature. Physiol Plant 33, 214-218

Smith PG, Dale JE (1988) The effects of root cooling and excision treatments on growth of primary leaves of Phaseolus vulgaris L New Phytol 110, 293-300

Stoker R, Weatherley PE (1971) The influence of the root system on the relationship between the rate of transpiration and depression of leaf water potential. New Phytol 70, 547-554

Van Den Honert TH (1948) Water transport in plants as a catenary process. Discuss Faraday Soc 3, 146-153

Vesque $J(1878)$ De l'influence de la température du sol sur l'absorption de l'eau par les racines. Ann Sci Nat Bot 6, Ser 6, 169-222

Wilson JM (1983) Interaction of chilling and water stress. In: Crop reactions to water and temperature stresses in humid, temperate climates (Raper CD Jr, Kramer PJ, eds), Westview Press, Boulder, Co (USA), 133-147 